\title{
PENGARUH LOAN TO DEPOSITS RATIO, FIRM SIZE DAN DEBT TO ASSET RATIO TERHADAP RETURN ON ASSETS (Pada Perusahaan Perbankan Yang Terdaftar Di Bursa Efek Indonesia Tahun 2015-2019)
}

\author{
Ng Husin ${ }^{1}$ Atika Purnamasari ${ }^{2}$ \\ Jurusan Akuntansi, Sekolah Tinggi Ilmu Ekonomi Ppi \\ Email: husin@stieppi.ac.id
}

\begin{abstract}
This study aims to examine the effect of loan to deposits ratio, firm size and debt to asset ratio on return on assets in banking companies listed on the indonesia stock exchange 2015-2019. The research method used is hypothesis or causal testing. This study uses quantitative secondary data in the form of financial statements for the 2015-2019 period from banking companies listed on the indonesia stock exchange which were taken as a sample of 7 companies. The statistical analysis used in this study is multiple regression analysis, while the hypothesis testing used is the $t$ test, $r$ test, and the determinant coefficient ( $r 2$ ). The results of the research show that (1) Loan to deposits ratio has an effect on return on assets, (2) Firm size has an effect on return on assets, (3) Debt to asset ratio has an effect on return on assets, (4) Simultaneously loan to deposits ratio, firm size and debt to asset ratio has an effect on return on assets
\end{abstract}

Keywords : Loan to Deposits Ratio, Firm Size, Debt to Asset Ratio and Return On Assets

\section{PENDAHULUAN}

Bank merupakan badan usaha lembaga keuangan yang menjual jasa dan kepercayaan, maka setiap bank berusaha sebanyak mungkin menarik nasabah baru, memperbesar dananya dan pemberian kredit dan jasa-jasanya. Namun bank harus bisa bersaing untuk mendapatkan dana sebagai modal bank dari para investor dalam masyarakat. Investor tentu akan menginvestasikan modalnya pada bank yang dapat memberikan keuntungan yang tinggi. Keuntungan yang pada umumnya hanya dapat dipenuhi oleh bank yang mempunyai kinerja yang baik.Salah satu ukuran untuk melihat kinerja keuangan perbankan adalah melalui return on asset (ROA).

Return on asset (ROA) adalah rasio yang menunjukan kemamp uan perusahaan menghasilkan laba dari aktiva yang dipergunakan (Sartono, 2015). Rasio ini penting bagi pihak manajemen untuk mengevaluasi efektivitas dan efisiensi manajemen perusahaan dalam mengelola seluruh aktiva perusahaan (Sudana, 2019). Semakin besar ROA, berarti semakin efisien penggunaan aktiva perusahaan atau dengan kata lain dengan jumlah aktiva yang sama bisa dihasilkan laba yang lebih besar, dan sebaliknya (Sudana, 2019). Berdasarkan fenomena yang terjadi, kemampuan bank mencetak laba mulai kendor. Hal ini tercermin dari return on asset perbankan per September 2019 yang mulai seret. Otoritas Jasa Keuangan Mencatat hingga akhir kuartal III 2019 lalu posisi ROA perbankan ada di level 2,48\%. Posisi ini turun tipis dari periode tahun sebelumnya sebesar $2,5 \%$. 


\section{Rata-rata Return On Asset Bank Umum Konvensional Periode Tahun 2015-2019}

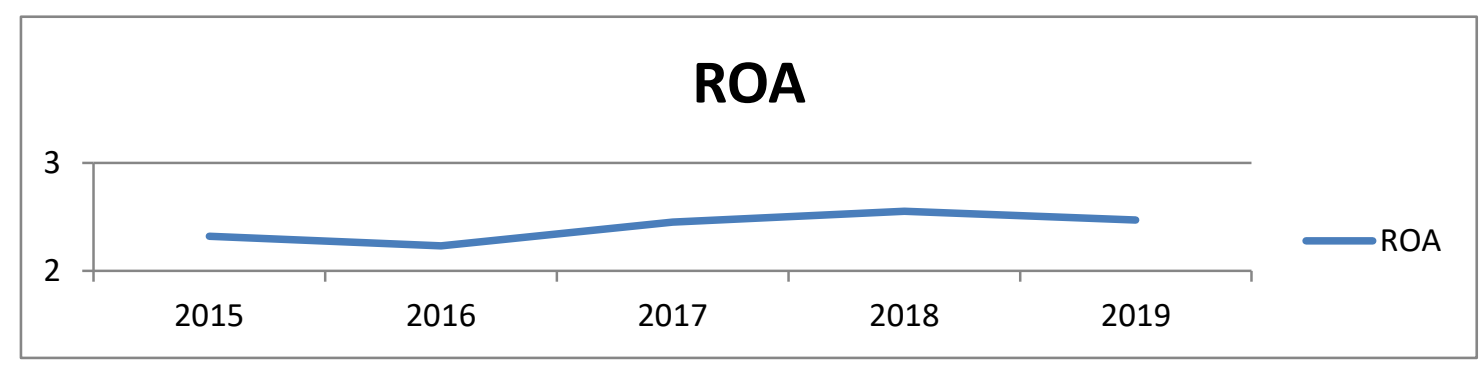

Sumber : Statistik Perbankan Indonesia, 2020

Tingkat kesehatan bank dapat dinilai dari beberapa indikator. Salah satu sumber utama indikator yang dijadikan dasar penilaian adalah laporan keuangan bank yang bersangkutan. Berdasarkan laporan itu akan dapat dihitung sejumlah rasio keuangan yang lazim dijadikan dasar penilaian tingkat kesehatan bank. Ada beberapa rasio yang mempengaruhi kinerja keuangan ROA bank, yaitu loan to deposit ratio. Loan to deposit ratio (LDR) mencerminkan kemampuan bank dalam membayar kembali penarikan dana yang dilakukan deposan dengan mengandalkan kredit yang diberikan sebagai sumber likuiditasnya, dengan kata lain seberapa jauh pemberian kredit kepada nasabah dapat mengimbangi kewajiban bank untuk segera memnuhi permintaan deposan yang ingin menarik kembali uangnya yang digunakan oleh bank untuk memberikan kredit yang diberikan dengan total dana pihak ketiga. Tujuan perhitungan LDR adalah untuk mengetahui serta menilai sampai seberapa jauh bank memiliki kondisi sehat dalam menjalankan operasi atau kegiatan usahanya.

Rasio kedua yang dapat mempengaruhi kinerja ROA perbankan adalah firm size. Firm size atau ukuran perusahaan adalah suatu skala dimana perusahaan diklasifikasikan menurut besar kecilnya berdasarkan pada total aktiva suatu perusahaan, semakin besar total aktiva maka semakin besar pula ukuran perusahaan tersebut. Perusahaan yang memiliki ukuran yang lebih besar mempunyai pengaruh terhadap peningkatkan profitabilitas perusahaan dan nilai perusahaan. Rasio ketiga adalah debt to asset ratio, dimana DAR adalah pengukuran yang digunakan untuk menghitung analisis leverage. Debt to asset ratio (DAR) merupakan salah satu rasio yang digunakan untuk mengukur seberapa besar jumlah aktiva perusahaan yang dibiayai oleh hutang. Semakin tinggi debt to asset ratio (DAR) maka semakin besar modal pinjaman dan semakin besar kewajiban perusahaan dalam membayar hutang jangka panjang pada perusahaan tersebut.

Manfaat teoritis Penelitian ini diharapkan dapat menjadi bahan referensi untuk penelitian sejenis yang tertarik melakukan penelitian selanjutnya. Dalam penelitian ini juga diharapkan dapat memberikan wawasan di bidang perbankan khususnya dalam hal yang berkaitan dengan kinerja Return On Asset pada perbankan. Manfaat praktis Penelitian ini dapat menjadi bahan bagi perbankan dalam mengambil keputusan dan tindakan yang akan diambil terhadap faktor-faktor yang dapat mempengaruhi tingkat Return On Asset bank sehingga operasionalnya tetap berjalan baik. Untuk OJK dapat digunakan sebagai bahan pertimbangan selaku regulator agar selalu memantau setiap kinerja perbankan di Indonesia agar terus meningkat dan Bagi nasabah dan investor diharapkan dapat memberikan wawasan dalam mengambil keputusan untuk memilih perbankan, sehingga nasabah dan investor mempunyai gambaran tentang keadaan atau kondisi perbankan yang dapat memberikan keuntungan bagi mereka. 


\section{TINJAUAN PUSTAKA}

\section{Signaling theory}

Signaling theory dikemukakan oleh Spence (1973), teori ini menjelaskan bagaimana sebuah perusahaan memberi sinyal pada para pengguna laporan keuangan seperti investor, sinyal ini merupakan informasi mengenai usaha manajemen dalam mewujudkan keinginan pemilik perusahaan yang menyatakan perusahaan tersebut lebih unggul dibanding perusahaan lain. Secara garis besar signalling theory erat kaitanya dengan ketersedian informasi.

\section{Loan To Deposit Ratio}

Loan To Deposit Ratio merupakan rasio yang digunakan untuk mengukur komposisi jumlah kredit yang diberikan dibandingkan dengan jumlah dana masyarakat dan modal sendiri yang digunakan (Andrianto, 2019). Suatu bank dapat menyalurkan kreditnya dalam batas toleransi yang ditetapkan, ini mengindikasikan bahwa bank tersebut dalam menyalurkan dananya secara efisien. Artinya, bank akan mendapatkan tambahan pendapatan dari bunga yang dibebankan kepada deposan (dengan asumsi tidak ada kredit macet). Peningkatan LDR akan memicu peningkatan ROA karena semakin tingginya pendapatan bunga yang dihasilkan (Akbar, 2019). Rasio LDR yang ideal menurut BI adalah 75\%-80\% (Fauziah, 2017).

\section{Firm Size}

Menurut Rahmawati (2015) ukuran perusahaan merupakan ukuran yang menggambarkan besar kecilnya suatu perusahaan yang dilihat dari seberapa besar total aset, total penjualan, dan jumlah karyawan yang dimiliki oleh perusahaan. Semakin besar aset, penjualan dan karyawan perusahaan maka akan semakin besar pula ukuran perusahaan begitupun sebaliknya semakin kecil aset, penjualan dan karyawan perusahaan maka semakin kecil pula ukuran perusahaan tersebut. Kriteria ukuran perushaan yang diatur dalam UU No. 20 Tahun 2008 adalah sebagai berikut :

\section{Debt To Asset Ratio}

Debt to Asset Ratio (DAR) merupakan rasio utang yang digunakan untuk mengukur perbandingan antara total utang dengan total aktiva. Dengan kata lain, seberapa besar aktiva perusahaan dibiayai oleh utang atau seberapa besar utang perusahaan berpengaruh terhadap pengelolaan aktiva (Kasmir, 2017). Debt to Asset Ratio (DAR). Rasio ini menekankan pentingnya pendanaan hutang dengan jalan menunjukkan persentase aktiva perusahaan yang didukung oleh hutang. Dengan kata lain, seberapa besar aset perusahaan dibiayai oleh hutang dan seberapa besar hutang perusahaan berpengaruh terhadap pengelolaan aset (Kasmir, 2017).

\section{Return On Asset}

Return on Aset (ROA) menunjukan seberapa besar efektivitas perusahaan dalam mengelola asset baik dari modal sendiri maupun dari modal pinjaman, investor akan melihat seberapa efektif suatu perusahaan dalam mengelola asset (Kasmir, 2017). Bank harus terus meningkatkan ROA karena publikasi rasio kinerja keuangan sangat cepat informasinya didapatkan oleh investor (Fauziah, 2017). Menurut ketentuan Bank Indonesia, standar yang paling baik untuk ROA dalam ukuran bank-bank Indonesia adalah minimal 1,5\% (Ovami, 2018). Semakin besar nilai $R O A$ artinya semakin baik kemampuan perbankan dalam menghasilkan laba. 
Kerangka Pemikiran

Berikut ini adalah kerangka yang digunakan dalam penelitian ini :

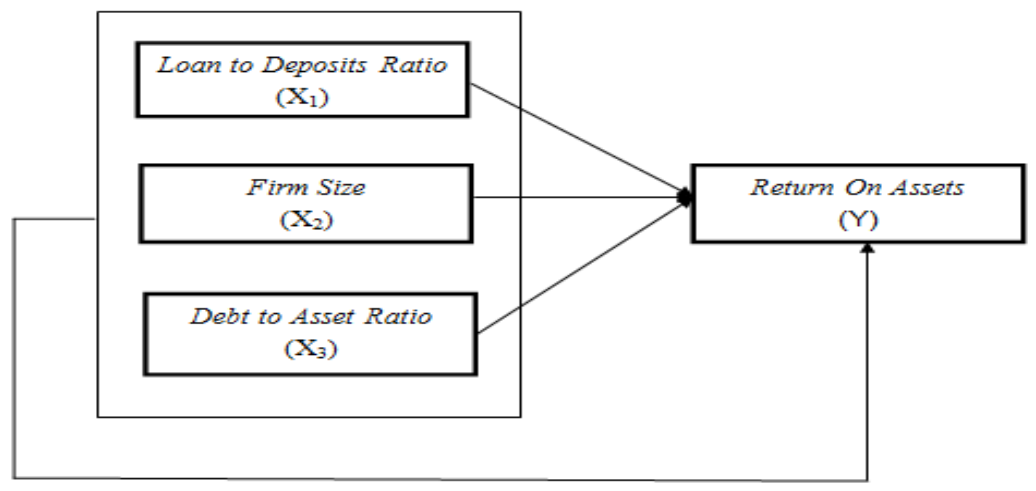

Gambar 1. Skema Kerangka Pemikiran

\section{Jenis Penelitian}

\section{METODE PENELITIAN}

Jenis penelitian ini adalah penelitian kuantitatif. Penelitian kuantitatif adalah data yang berupa angka. Sesuai dengan bentuknya, data kuantitatif dapat dioleh atau dianalisi dengan menggunakan teknik perhitungan statistic dengan SPSS 23. Data yang diperoleh melalui annual report yang dipublikasikan melalui website resmi Bursa Efek Indonesia (BEI) yaitu www.idx.co.id. Untuk menentukan sampel dalam penelitian ini, peneliti menggunakan teknik pengambilan purposive sampling. Analisis data yang digunakan dalam penelitian ini adalah analisis statistik deskriptif disertai dengan uji asumsi yaitu uji asumsi dasar dan uji asumsi klasik. Uji analisis data dan uji hipotesis menggunakan analisis regresi berganda, analisa koefisien determinasi $\left(\mathrm{R}^{2}\right)$, uji signifikansi Parameter individual (uji statistik t), dan uji signifikansi simultan (uji statistik F).

\section{Definisi Operasional Dan Pengukuran Variabel}

Variabel yang digunakan dalam penelitian ini terdiri dari Return On Assets sebagai variabel dependen dan beberapa variabel independen yaitu Loan to Deposits Ratio, Firm Size dan Debt to Asset Ratio.

\section{Variabel Dependen (Y)}

Variabel dependen yang digunakan dalam penelitian ini adalah Return on Aset. Return on Aset (ROA) menunjukan seberapa besar efektivitas perusahaan dalam mengelola asset baik dari modal sendiri maupun dari modal pinjaman, investor akan melihat seberapa efektif suatu perusahaan dalam mengelola asset (Kasmir, 2017). Berdasarkan pernyataan Kasmir (2017) maka dapat dirumuskan sebagai berikut:

\begin{tabular}{|c|c|c|c|}
\hline \multirow{2}{*}{ ROA } & Laba Bersih Setelah Pajak & \multirow{2}{*}{$x$} & \multirow{2}{*}{$100 \%$} \\
\hline & Total Aktiva & & \\
\hline
\end{tabular}




\section{Variabel Independen $(\mathrm{X})$}

Variabel independen yang digunakan dalam penelitian ini adalah:

a. Loan to Deposits Ratio $\left(\mathrm{X}_{1}\right)$

LDR (Loan to Deposits Ratio) adalah rasio yang menunjukan kemampuan bank dalam memenuhi kewajiban jangka pendek (likuiditas) dengan membagi total kredit terhadap total Dana Pihak Ketiga (DPK). Likuiditas perbankan perlu dikelola untuk memenuhi kebutuhan saat nasabah mengambil dananya dan menyalurkan pinjaman (kredit) kepada peminjam (debitur). Jika nilai loan to deposits ratio terlalu tinggi, artinya perbankan tidak memiliki likuiditas yang cukup memadai untuk menutup kewajibannya terhadap nasabah (DPK) Sebaliknya, jika nilai loan to deposits ratio terlalu rendah berarti perbankan memiliki likuiditas yang cukup memadai tetapi mungkin pendapatannya lebih rendah, karena seperti yang diketahui dunia perbankan memperoleh pendapatan melalui kredit yang disalurkan. LDR dapat dihitung dengan cara:

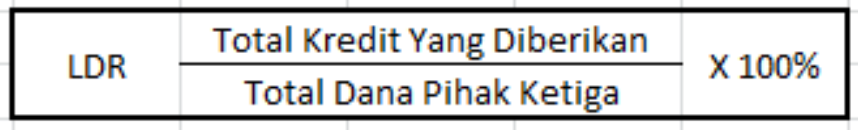

b. Firm Size $\left(\mathrm{X}_{2}\right)$

Firm size atau sering disebut ukuran perusahaan adalah suatu skala dimana dapat diklasifikasikan besar kecilnya perusahaan menurut berbagai cara antara lain dengan total aktiva, log size, nilai pasar saham, dan lain-lain. Menurut Hartono (2015) ukuran perusahaan adalah besar kecilnya perusahaan dapat diukur dengan total aktiva/besar harta perusahaan dengan menggunakan perhitungan nilai logaritma total aktiva. Adapun rumus yang digunakan adalah:

\section{SIZE $=$ LN ( TOTAL AKTIVA)}

c. Debt to Asset Ratio $\left(\mathrm{X}_{3}\right)$

Debt to asset ratio merupakan rasio yang menunjukan pentingnya pendanaan hutang dengan jalan menunjukkan persentase aktiva perusahaan yang didukung oleh hutang. Dengan kata lain, seberapa besar aset perusahaan dibiayai oleh hutang dan seberapa besar hutang perusahaan berpengaruh terhadap pengelolaan aset (Kasmir, 2017). Rumus yang digunakan yaitu :

\begin{tabular}{|l|l|l|}
\hline \multirow{2}{*}{ DAR } & TOTAL UTANG & \multirow{2}{*}{$100 \%$} \\
\cline { 2 - 2 } & TOTAL AKTIVA & \\
\hline
\end{tabular}

\section{Uji Kualitas Data}

\section{Uji Statistik Deskriptif}

Analisis statistik deskriptif diperlukan untuk mengetahui gambaran atau deskripsi dari data yang akan digunakan, dilihat dari nilai rata-rata (mean), median maximum, dan minimum.

\section{Uji Asumsi Klasik}

a. Uji Normalitas

Uji normalitas berguna untuk menentukan data yang telah dikumpulkan berdistribusi normal atau diambil dari populasi normal (Ghozali, 2018). Uji statistik normalitas yang dapat digunakan diantaranya Kolmogorov Smirnov. 
b. Uji Multikolinieritas

Menurut Ghozali (2018) Uji multikolonearitas adalah adanya hubungan linear antara variabel bebas X dalam Model Regresi Ganda. Pendeteksian multikolinearitas dapat dilihat melalui nilai variance inflation factors (VIF). Kriteria pengujian yaitu apabila nilai VIF < 10 maka tidak terdapat multikoliniearitas di antara variabel independent dan sebaliknya.

c. Uji AutoKorelasi

Uji Autokorelasi digunakan untuk mengetahui ada atau tidaknya penyimpanan asumsi autokorelasi yang terjadi diantaranya residual pada saat pengamatan dengan pengamatan lain pada model regresi (Ghozali, 2018). Untuk mendeteksi ada atau tidaknya autokorelasi dapat dilakukan dengan uji Durbin - Watson (DW test).

d. Uji Heteroskedastisitas

Uji heteroskedatisitas bertujuan menguji apakah dalam regresi terjadi ketidaksamaan variance idari residual satu pengamatan ke pengamatan yang lain (Ghozali, 2018). Jika variance dari residual satu pengamatan ke pengamatan lain tetap, maka disebut homoskedasitisitas dan jika berbeda disebut heteroskedasitisitas dengan uji glejser.

\section{Uji Hipotesis}

a. Analisis Regresi Linear Berganda

Regresi linier ganda atau majemuk digunakan untuk memodelkan hubungan antara variabel dependen dan variabel independen, dengan jumlah variabel independen yang lebih dari satu.

b. Koefisien Determinan $\left(\mathrm{R}^{2}\right)$

Menurut Ghozali (2018) Uji Koefisien Determinasi $\left(\mathrm{R}^{2}\right)$ digunakan untuk mengetahui presentase pengaruh variabel independen (predikator) terhadap perubahan variabel dependen. Nilai yang mendekati satu variabel-variabel independen memberikan hampir semua informasi yang dibutuhkan oleh memprediksi variasi variabel dependen.

c. Uji Statistik t (Uji Parsial)

Uji ini digunakan untuk menguji tingkat signifikansi pengaruh masing-masing variabel independen terhadap variabel dependen. Dengan tingkat signifikansi 5\%, apabila nilai signifikansi $\mathrm{t}<0.05$, maka Ho akan ditolak, artinya terdapat pengaruh yang signifikan antara satu variabel independen terhadap variabel dependen. Apabila nilai signifikansi t $>0.05$, maka Ho akan diterima, artinya tidak terdapat pengaruh yang signifikan antara satu variabel independen terhadap variabel dependen.

d. Uji Statisitik F (Uji Simultan)

Uji ini pada dasarnya menunjukkan apakah semua variabel independen yang digunakan dalam penelitian mempunyai pengaruh secara simultan terhadap variabel dependen. Pengujian ini dilakukan dengan menggunakan tingkat signifikansi 5\%. Jika nilai signifikansi $\mathrm{f}<0,05$ artinya terdapat pengaruh yang signifikan antara semua variabel independen terhadap variabel dependen. Jika nilai $\mathrm{f}>0,05$ artinya tidak terdapat pengaruh antara variabel independen terhadap variabel dependen (Ghozali, 2018).

\section{HASIL PENELITIAN DAN PEMBAHASAN}

Penelitian ini mengambil sampel perusahaan sektor perbankan yang terdaftar di Bursa Efek Indonesia tahun 2015-2019 dan mengambil data laporan keuangan perusahaan perbankan yang memiliki modal inti diatas sebesar Rp. 30 triliun pada tahun periode 2015-2019. Pada awalnya perusahaan yang bergerak di sektor perbankan yang 
terdaftar di BEI sebanyak 45 perusahaan, lalu penelitian ini dipilih kembali berdasarkan sampel yang akan diteliti dengan beberapa kriteria tertentu untuk mendapatkan hasil untuk dilakukan penelitian sehingga mendapatkan sampel akhir penelitian sebanyak 7 perusahaan dan dikalikan selama 5 tahun pengamatan maka menghasilkan 35 sampel penelitian.

Tabel 1. Daftar Perusahaan Yang Menjadi Sampel Penelitian

\begin{tabular}{|c|c|l|}
\hline NO & KODE & \multicolumn{1}{c|}{ NAMA BANK } \\
\hline 1 & BBRI & PT. BANK RAKYAT INDONESIA Tbk \\
\hline 2 & BBNI & PT. BANK NEGARA INDONESIA Tbk \\
\hline 3 & BMRI & PT. BANK MANDIRI Tbk \\
\hline 4 & BBCA & PT. BANK CENTRAL ASIA Tbk \\
\hline 5 & BNGA & PT. BANK CIMB NIAGA Tbk \\
\hline 6 & BDMN & PT. BANK DANAMON INDONESIA Tbk \\
\hline 7 & PNBN & PT. BANK PANIN Tbk \\
\hline
\end{tabular}

\section{Uji Statistik Deskriptif}

Tabel 2. Hasil Uji Statistik Deskriptif

\begin{tabular}{|l|c|c|c|c|c|}
\hline & N & Min & Max & Mean & $\begin{array}{c}\text { Std. } \\
\text { Deviation }\end{array}$ \\
\hline Loan to Deposits Ratio & 35 & 77,10 & 115,26 & 91,3129 & 7,69506 \\
\hline Firm Size & 35 & 25,88 & 27,98 & 26,9031 & 0,75871 \\
\hline Debt to Asset Ratio & 35 & 76,53 & 87,99 & 82,5169 & 3,09791 \\
\hline Return On Assets & 35 & 0,24 & 4,19 & 2,7120 & 0,97039 \\
\hline Valid N (listwise) & 35 & & & & \\
\hline
\end{tabular}

Sumber: Output SPSS 23

\section{Uji Asumsi Klasik}

Uji Normalitas Data

Tabel 3. Uji Normalitas Non Parametik Kolmogorov-Smirnov (K-S)

\begin{tabular}{|ll|r|}
\hline & & $\begin{array}{c}\text { Unstandardized } \\
\text { Residual }\end{array}$ \\
\hline $\mathrm{N}$ & 35 \\
Normal Parameters & Mean &, 0000000 \\
& Std. &, 64136498 \\
Most Extreme & Deviation &, 080 \\
Differences & Absolute & \\
& Positive &, 074 \\
Test Statistic & Negative &,- 080 \\
Asymp. Sig. (2-tailed) & &, 080 \\
\end{tabular}

Sumber: Output SPSS 23

a. Test distribution is Normal. 
Berdasarkan uji normalitas menunjukkan bahwa data yang diperoleh tersebut mengikuti distribusi normal, berdasarkan hasil output menunjukkan nilai Asymp.Sig (2tailed) $0,200>0,05$, dengan residual data berdistribusi normal dan dapat dilanjutkan dengan uji asumsi klasik lainnya.

\section{Uji Multikolinieritas}

Tabel 4. Uji Multikolinieritas

\section{Coefficients $^{a}$}

\begin{tabular}{|l|r|r|}
\hline \multirow{2}{*}{ Model } & \multicolumn{2}{|c|}{ Collinearity Statistics } \\
\cline { 2 - 3 } & Tolerance & \multicolumn{1}{|c|}{ VIF } \\
\hline 1(Constant) & & \\
Loan to Deposits Ratio & 0,639 & 1,566 \\
Firm Size & 0,652 & 1,533 \\
Debt to Asset Ratio & 0,962 & 1,039 \\
\hline
\end{tabular}

Sumber: Output SPSS 23

a. Dependent Variable: Return On Assets

Berdasarkan hasil uji multikolinieritas diatas, dapat disimpulkan bahwa semua variabel independen dalam model regresi tidak terdapat gejala multikolinieritas.

\section{Uji Autokorelasi}

Tabel 5. Uji Autokorelasi

Model Summary ${ }^{b}$

\begin{tabular}{|r|r|r|r|r|r|}
\hline $\begin{array}{r}\text { Mode } \\
1\end{array}$ & $\mathrm{R}$ & $\mathrm{R}$ Square & $\begin{array}{c}\text { Adjusted R } \\
\text { Square }\end{array}$ & $\begin{array}{c}\text { Std. Error of the } \\
\text { Estimate }\end{array}$ & $\begin{array}{r}\text { Durbin- } \\
\text { Watson }\end{array}$ \\
\hline 1 &, $741^{2}$ &, 549 &, 504 &, 53744 & 1,973 \\
\hline
\end{tabular}

Maka dapat disimpulkan nilai $\mathrm{DW}$ berada diantara $\mathrm{DU}<\mathrm{DW}<4-\mathrm{DU}=1,6528$ $<1,973<2.3472$ termasuk ke dalam kriteria bebas autokorelasi.

\section{Uji Heteroskedastisitas}

Tabel 6. Uji Heterokedastisitas

\begin{tabular}{|c|c|c|c|c|c|}
\hline \multirow[b]{2}{*}{ Model } & \multicolumn{2}{|c|}{ Unstandardized Coefficients } & $\begin{array}{r}\text { Standardized } \\
\text { Coefficients }\end{array}$ & \multirow[b]{2}{*}{$\mathrm{T}$} & \multirow[b]{2}{*}{ Sig. } \\
\hline & $\mathrm{B}$ & Std. Error & Beta & & \\
\hline (Constant) &,- 452 & 4,194 & &,- 108 & ,915 \\
\hline Loan to Deposits Ratio & ,003 &, 011 &, 055 & ,248 &, 806 \\
\hline Firm Size &, 057 & ,112 &, 111 &, 505 & ,617 \\
\hline Debt to Asset Ratio &,- 010 & 023 &,- 080 &,- 440 & ,663 \\
\hline
\end{tabular}

a. Dependent Variable: Return On Assets

Berdasarkan hasil uji heteroskedastisitas diatas, menunjukkan bahwa semua nilai signifikansi lebih besar dari 0,05, sehingga dapat disimpulkan bahwa tidak terjadi gejala heteroskedastisitas. 
Uji Hipotesis

Analisis Regresi Linier Berganda

Tabel 7. Hasil Analisis Regresi Linier Berganda

Coefficients $^{a}$

\begin{tabular}{|c|c|c|c|c|c|}
\hline \multirow{2}{*}{ Model } & \multicolumn{2}{|c|}{$\begin{array}{c}\text { Unstandardized } \\
\text { Coefficients }\end{array}$} & $\begin{array}{c}\text { Standardized } \\
\text { Coefficients }\end{array}$ & & \\
\cline { 2 - 4 } & $\mathrm{B}$ & Std. Error & Beta & & \\
\hline 1 (Constant) &,- 507 & 7,015 & &,- 072 &, 943 \\
Loan to Deposits Ratio &,- 053 &, 019 &,- 423 & $-2,851$ &, 008 \\
Firm Size &, 541 &, 188 &, 423 & 2,877 &, 007 \\
Debt to Asset Ratio &,- 078 &, 038 &,- 250 & $-2,065$ &, 047 \\
\hline
\end{tabular}

$\mathrm{Y}=\mathrm{a}+\mathrm{b}_{1} \cdot \mathrm{X}_{1}+\mathrm{b}_{2} \cdot \mathrm{X}_{2}+\mathrm{b}_{3} \cdot \mathrm{X}_{3}$

$\mathrm{Y}=-0,507+(-0,053) \mathrm{X}_{1}+0,541 \mathrm{X}_{2}+(-0,078) \mathrm{X}_{3}$

$\mathrm{Y}=-0,507-0,053 \mathrm{X}_{1}+0,541 \mathrm{X}_{2}-0,078 \mathrm{X}_{3}$

Uji Koefisien Determinasi $\left(\mathbf{R}^{2}\right)$

Tabel 8. Hasil Uji Koefisien Determinasi (R2)

\begin{tabular}{|c|c|c|c|c|}
\hline Model & $\mathrm{R}$ & $\begin{array}{c}\mathrm{R} \\
\text { Square }\end{array}$ & $\begin{array}{c}\text { Adjusted R } \\
\text { Square }\end{array}$ & $\begin{array}{l}\text { Std. Error of the } \\
\text { Estimate }\end{array}$ \\
\hline &, $750^{\mathrm{a}}$ & ,563 & 521 & ,67168 \\
\hline
\end{tabular}

Model Summary

Hasil perhitungan adjusted $R$ Square $\left(\mathrm{R}^{2}\right)$ diperoleh angka koefisien determinasi $\mathrm{R}^{2}=$ 0,521 atau $52,1 \%$. Hal ini berarti kemampuan variabel independen yang terdiri dari Loan to Deposits Ratio, Firm Size dan Debt to Asset Ratio dalam menjelaskan variabel dependen yaitu Return On Assets sebesaar 52,1\%. sisanya (100\% - 52,1\% = 47,9\%) dipengaruhi oleh variabel lain di luar model yang diteliti dalam penelitian ini.

Uji Parsial (Uji t)

Tabel 9. Hasil Uji Parsial (t)

Coefficients ${ }^{a}$

\begin{tabular}{|l|c|c|}
\hline Model & T & Sig. \\
\hline 1 (Constant) &,- 072 &, 943 \\
Loan to Deposits Ratio & $-2,851$ &, 008 \\
Firm Size & 2,877 &, 007 \\
Debt to Asset Ratio & $-2,065$ &, 047 \\
\hline
\end{tabular}

Berdasarkan hasil pengujian secara parsial, dapat dijelaskan bahwa:

1. Nilai Signifikan sebesar 0,008 $<0,05$ sehingga dapat disimpulkan bahwa secara parsial Loan to Deposits Ratio berpengaruh signifikan terhadap Return On Assets.

2. Nilai Signifikan sebesar 0,007 <0, 05 sehingga dapat disimpulkan bahwa Firm Size 
berpengaruh signifikan terhadap Return On Assets.

3. Nilai Signifikan sebesar 0,047 <0,05 Sehingga dapat disimpulkan bahwa secara parsial Debt to Asset Ratio berpengaruh terhadap Return On Assets.

Uji Simultan (Uji F)

Hasil Uji Simultan (F) ANOVA $^{\mathrm{a}}$

\begin{tabular}{|l|c|c|c|c|r|}
\hline \multicolumn{1}{|c|}{ Model } & Sum of Squares & Df & Mean Square & F & Sig. \\
\hline Regression & 18,030 & 3 & 6,010 & 13,322 &, $000^{\mathrm{b}}$ \\
Residual & 13,986 & 31 &, 451 & & \\
Total & 32,016 & 34 & & & \\
\hline
\end{tabular}

a. $\quad$ Dependent Variable: Return On Assets

b. Predictors: (Constant), Loan to Deposits Ratio, Firm Size, Debt to Asset Ratio

Dari hasil perhitungan didapatkan bahwa nilai signifikan sebesar 0,000 $<0,05$. Sehingga dapat disimpulkan bahwa loan to deposits ratio, firm size dan debt to asset ratio secara simultan berpengaruh signifikan terhadap return on assets.

\section{Pembahasan}

\section{Pengaruh Loan to Deposits Ratio terhadap Return On Assets}

Berdasarkan hasil statistik uji t diketahui bahwa Nilai Signifikan sebesar 0,008 $<0,05$ sehingga dapat disimpulkan bahwa secara parsial loan to deposits ratio berpengaruh negatif signifikan terhadap return on assets dimana berarti bahwa semakin rendah rasio Loan to Deposit Ratio (LDR) maka semakin besar Return On Assets (ROA) atau profitabilitas yang diperoleh begitupun sebaliknya. Hal ini menunjukkan bahwa loan to deposits ratio sangat berkaitan erat dengan dana yang dimiliki oleh bank, maka suatu bank harus dapat menjaga likuiditasnya agar berada pada tingkat yang optimal. Dalam upaya untuk memenuhi kewajiban jangka pendeknya, bank harus dapat menyediakan sumber-sumber pembayaran yang dapat segera direalisasikan. Hasil pengaruh dari penelitian ini menunjukan berpengaruh negatif dari Loan to Deposit Ratio (LDR) terhadap Return On Assets (ROA) menunjukan bahwa rasio Loan to Deposit Ratio (LDR) menurun artinya bank yang bersangkutan mampu membayar kembali dana pihak ketiga sehingga semakin sedikit dari dana pihak ketiga yang belum terpenuhi, maka dapat diartikan juga bahwa kualitas likuiditas dari bank tersebut meningkat. Loan to Deposit Ratio berpengaruh signifikan terhadap Return On Assets hal ini dikarenakan dari meningkatnya kualitas likuiditas bank tersebut sehingga keuntungan yang diperoleh juga meningkat.

Hasil ini didukung juga oleh penelitian yang dilakukan oleh Dedi samsul arifin (2018), Riska malinda (2018) dan Ellysa Fransisca (2019) dengan hasil penelitian menyimpulkan bahwa variabel likuiditas yang diukur dengan loan to deposits ratio memiliki pengaruh terhadap return on assets.

\section{Pengaruh Firm Size terhadap Return On Assets}

Berdasarkan hasil statistik uji t diketahui bahwa Nilai Signifikan sebesar 0,007 $<0,05$ sehingga dapat disimpulkan bahwa firm size (ukuran perusahaan) berpengaruh signifikan terhadap return on assets. Hal ini menunjukkan dengan adanya hubungan positif antara firm size dengan return on assets maka semakin besar ukuran perusahaan maka, kemampuan perusahaan dalam menghasilkan profit atau laba dalam perusahaan akan semakin 
meningkat, begitu pula sebaliknya. Hal ini dikarenakan aktiva tinggi yang dimiliki bank tersebut cenderung akan menunjukan tingginya tingkat profitabilitas, selain itu bank juga akan mudah mendapat keuntungan karena terjadi pembiayaan yang rendah dan kredit lancar yang menyebabkan return yang dihasilkan menjadi besar, dengan kata lain firm size yang besar akan meningkatkan profitabilitas.

Hasil penelitian ini mendukung hasil penelitian yang dilakukan oleh Dedy samsul arifin (2018) yang menyimpulkan bahwa firm size mempunyai pengaruh signifikan terhadap return on assets.

\section{Pengaruh Debt to Asset Ratio terhadap Return On Assets}

Berdasarkan hasil statistik uji T diketahui bahwa Nilai Signifikan sebesar 0,047 < 0,05 Sehingga dapat disimpulkan bahwa secara parsial debt to asset ratio berpengaruh terhadap return on assets. Hal ini menunjukkan dengan adanya hubungan negatif signifikan antara DAR terhadap ROA. Artinya semakin tinggi tingkat rasio DAR maka rasio ROA akan semakin rendah dan sebaliknya. Nilai DAR yang tinggi menyebabkan nilai ROA perusahaan menjadi rendah. Hal ini disebabkan oleh pembayaran biaya-biaya yang timbul akibat hutang atau pinjaman sehingga mengurangi laba perusahaan. Laba perusahaan yang menurun menyebabkan nilai ROA menjadi rendah (Gunde, Murni, \& Rogi, 2017). Semakin tinggi nilai DAR berarti menunjukkan semakin besar sumber dana melalui hutangnya untuk membiayai aktiva. Nilai DAR yang tinggi menunjukkan risiko yang tinggi pula karena ada kekhawatiran perusahaan tidak mampu menutupi hutang-hutangnya dengan aktiva yang dimiliki sehingga untuk memperoleh tambahan pinjaman akan semakin sulit (Kasmir, 2017).

Hasil penelitian ini mendukung penelitian yang dilakukan oleh Azzahra \& Nasib (2019), dan Mawarsih, dkk (2020) menemukan hasil bahwa DAR berpengaruh negatif dan signifikan terhadap ROA.

\section{Pengaruh Loan to Deposits Ratio, Firm Size, dan Debt to Asset Ratio secara simultan terhadap Return On Assets}

Berdasarkan hasil statistik uji $\mathrm{F}$ pada tabel 4.11 diketahui bahwa $\mathrm{F}$ hitung sebesar 13,332 karena nilai signifikan $0,000<0,05$ sehingga dapat disimpulkan bahwa Loan to Deposits Ratio, Firm Size, dan Debt to Asset Ratio berpengaruh positif secara simultan terhadap Return on Asset (ROA) .

Dalam hal ini teori yang mendukung adalah Signalling Theory merupakan teori ini yang menjelaskan Sinyal pada pasar ini berupa informasi mengenai apa yang sudah dilakukan oleh manajemen untuk merealisasikan keinginan pemilik. Informasi yang dikeluarkan oleh perusahaan merupakan hal yang penting, karena pengaruhnya terhadap keputusan investasi pihak diluar perusahaan. Informasi tersebut penting bagi investor dan pelaku bisnis karena informasi pada hakekatnya menyajikan keterangan, catatan atau gambaran, baik untuk keadaan masa lalu, saat ini maupun masa yang akan datang bagi kelangsungan hidup perusahaan dan bagaimana efeknya pada perusahaan.

\section{KESIMPULAN}

1. Loan to Deposits Ratio berpengaruh negatif terhadap Return On Assets pada perusahaan perbankan yang terdaftar di Bursa Efek Indonesia (BEI) pada tahun 20152019.

2. Firm Size berpengaruh positif terhadap Return On Assets pada perusahaan perbankan yang terdaftar di Bursa Efek Indonesia (BEI) pada tahun 2015-2019. 
3. Debt to Asset Ratio berpengaruh negatif terhadap Return On Assets pada perusahaan perbankan yang terdaftar di Bursa Efek Indonesia (BEI) pada tahun 2015-2019.

4. Loan to Deposits Ratio, Firm Size, dan Debt to Asset Ratio berpengaruh positif secara simultan terhadap Return On Assets pada perusahaan perbankan yang terdaftar di Bursa Efek Indonesia (BEI) pada tahun 2015-2019.

Saran

1. Bagi Bank

Hasil penelitian ini diharapkan dapat digunakan sebagai bahan pertimbangan dalam mengambil tindakan untuk meningkatkan profitabilitas bank dengan memperhatikan rasio-rasio keuangan

2. Bagi Otoritas Jasa Keuangan (OJK)

Hasil penelitian ini diharapkan dapat menjadi bahan pertimbangan OJK selaku regulator agar selalu memantau setiap kinerja perbankan di Indonesia agar perkembangan bank di Indonesia terus meningkat.

3. Bagi Nasabah

Diharapkan dapat membantu nasabah dalam menilai tingkat kesehatan bank dan dapat mengetahui bagaimana kondisi perbankan di Indonesia.

4. Untuk penelitian berikutnya, perlu membandingkan jenis perusahaan sektor lain tidak hanya pada perusahaan perbankan saja. Penelitian ini diharapkan dapat menjadi sumber informasi untuk menambah pengetahuan dalam bidang lainnya misalnya pertanian (agriculture), real estate, telekomunikasi, transportasi, finance dan sektor lainnya sehingga mampu memperkuat hasil penelitian-penelitian yang telah dilakukan sebelumnya. 


\section{DAFTAR PUSTAKA}

Akbar, Taufiq. 2019, Kajian Kinerja Profitabilitas Bank pada Perspektif Bank Umum Berdasarkan Kegiatan Usaha (BUKU), Studi Empiris pada Momen Penurunan Profitabilitas Bank-Bank di Indonesia. Uwais Inspirasi Indo, Ponorogo.

Amalia Dewi Rahmawati. 2015.’Pengaruh Ukuran Perusahaan, Profitabilitas,Struktur Modal dan Keputusan Investasi Terhadap Nilai Perusahaan".

Andrianto. 2019, Manajemen Kredit: Teori dan Konsep Bagi Bank Umum, CV Penerbit Qiara Media, Jawa Timur.

Arifin,D.S., Sarita Buyung, Mardi,R.A (2018). Pengaruh Likuiditas, Leverage, Ukuran Perusahaan Dan Pertumbuhan Penjualan Terhadap Profitabilitas (Studi Pada Perusahaan Property Dan Real Estate Yang Terdaftar Di Bursa Efek Indonesia Tahun 2013- 2017), Universitas Halu Oleo, Kendari.

Azzahra, A. S., \& Nasib. (2019). Pengaruh Firm Size dan Leverage Ratio Terhadap Kinerja Keuangan Pada Perusahaan Pertambangan. JWEM STIE MIKROSKIL Vol 9 No 1.

Fauziah, Fenty. 2017, Kesehatan Bank, Kebijakan Dividen, dan Nilai Perusahaan Teori dan Kajian Empiris, RV Pustaka Horizon, Samarinda, Kalimantan Timur.

Fransisca, E., \& Widjaja, I . (2019) . Pengaruh Leverage, Likuiditas, Pertumbuhan Penjualan Dan Ukuran Perusahaan Terhadap Profitabilitas Perusahaan Manufaktur. Jurnal Manajerial Dan Kewirausahaan, 1(2), 199-206.

Ghozali, I. (2018). Aplikasi Analisis Multivariate dengan Program IBM SPSS.

Gunde, Yulita M, Sri Murni, Mirah H. Rogi.2017."Analisis Pengaruh Leverage Terhadap Profitabilitas pada Perusahaan Manufaktur Sub Industri Food and Beverages yang Terdaftar di BEI (Periode 2012-2015)". Jurnal EMBA 5 (3).

Hartono, Jogiyanto. 2015. Teori Portofolio dan Analisis Investasi Edisi Kesepuluh. Yogyakarta: BPFE.

Kasmir. 2017. Analisis Laporan Keuangan. Jakarta: PT Raja Grafindo Persada.

Kontan.co.id (2019), ROA Perbankan Turun ke 2,48\% per September 2019, Diakses 10 September 2020, dari https://keuangan.kontan.co.id/news/roaperbankan-turun-ke248-per-september-2019.

Mailinda, R. (2018). Pengaruh Leverage, Likuiditas, dan Ukuran Perusahaan terhadap Profitabilitas pada BNI Syariah di Indonesia Periode 2015-2017 (Doctoral dissertation, UIN Ar-Raniry Banda Aceh).

Mawarsih, S., Ramadhan, F., Irawati, L., \& Adhillah, N. (2020). Total Assets Turnover, Deb To Assets Ratio, Dan Debt To Equity Ratio Terhadap Return On Assets Pada Perusahaan Sub Sektor Asuransi. Al-Mashrafiyah Vol 4 No 1.

Ovami, D. C. 2018. Pengaruh Non Performing Loan (Npl) Dan Return On Asset (Roa) Terhadap Penyaluran Kredit Pada Pt Bank Sumut Kcp Marendal Medan. Kajian Akuntansi Volume 19 No.1, 95.

Sartono, A. (2015). Manajemen Keuangan Teori dan Aplikasi (4 ed.). Yogyakrta: BPFE Yogyakarta.

Spence, M., 1973. Job market signaling. Quarterly Journal of Economics, 87: 355- 374.

Sudana, I. (2019). Manajemen Keuangan Perusahaan (Edisi Kedua ed.). Jakarta: Erlangga. 
Tegor., Siswanto, Dwi Joko., Siagian, Mauli. (2020). Manajemen Sumber Daya Manusia. Yoyakarta. Penerbit Deepublish.

Tegor, T., Juliza, Yusmalina, \& Haqiqi, F. (2021). Penerapan Standar Akuntansi dan Kualitas Aparatur Terhadap Laporan Keuangan Pemerintah Daerah (Studi Kasus pada Dinas Pekerjaan Umum dan Penataan Ruang Kabupaten Karimun). JURNAL CAFETARIA, 2(1), 13-24. https://doi.org/10.51742/akuntansi.v2i1.276. 